Corporate Strategy 
Also by W. Stewart Howe

Competition in British Industry (with D. Swann et al.)

Case Studies in Competition Policy (with K. Blois)

Industrial Economics

Competition Policy, Profitability and Growth

(with D. P. O'Brien et al.)

The Dundee Textiles Industry 1960-1977 


\section{CORPORATE STRATEGY}

W. Stewart Howe

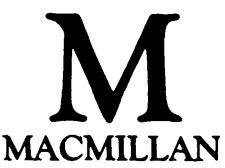


(C) W. Stewart Howe 1986

All rights reserved. No reproduction, copy or transmission of this publication may be made without written permission.

No paragraph of this publication may reproduced, copied or transmitted save with permission or in accordance with the provisions of the Copyright Act 1956 (as amended).

Any person who does any unauthorised act in relation to this publication may be liable to criminal prosecution and civil claims for damages.

First published 1986

Published by MACMILLAN EDUCATION LTD

Houndmills, Basingstoke, Hampshire RG21 2XS and London

Companies and representatives throughout the world

British Library Cataloguing in Publication Data Howe, W. Stewart

Corporate strategy.

1. Corporate planning

I. Title 658.4'012 HD30.28 
To the memory of my Father and Mother 


\section{Contents}

Acknowledgements

$\mathbf{X}$

Introduction

$\mathbf{x i i}$

\section{PART I THE STRATEGIC MANAGEMENT PROCESS}

1 Strategic Management 3

11.1 Definitions 3

1.2 Comparisons 4

1.3 The Strategic Management Process 7

1.4 The Importance of Strategy $\quad 10$

1.5 Conclusions 13

2 Business Objectives 16

2.1 Introduction 16

2.2 Determinants of Objectives 18

2.3 Business Objectives in Practice 22

2.4 Conclusions $\quad 27$

3 Assessment of the Business Environment and 29

3.1 Introduction 29

3.2 The External Environment: Opportunities and Threats 32

3.3 The Internal Business Audit: Strengths and Weaknesses 40

3.4 Combined Analysis of Environment and Resources $\quad 44$

3.5 Conclusions 48 
Strategic Possibilities

4.1 Introduction 53

4.2 The Range of Strategies $\quad 54$

4.3 Expansion Strategies $\quad 54$

4.4 Status Quo $\quad 60$

4.5 Contraction $\quad 62$

4.6 Conclusions 64

5trategic Comparisons 66

5 5.1 Introduction 66

5.2 The Boston Consulting Group Matrix 67

5.3 The Shell Directional Policy Matrix 76

5.4 Conclusions $\quad 78$

6 Strategic Decision-Making and Implementation 85

6.1 Introduction $\quad 85$

6.2 The Decision-Making Process 87

6.3 Strategic Implementation 95

6.4 An Example 103

6.5 Conclusions 106

Appendix: The Long Search That Led to Howard Johnson's Door

\section{PART II ANALYSIS OF STRATEGIES}

7 Business Growth $\quad 117$

7.1 Introduction 117

7.2 Incentives to Growth 118

7.3 Constraints upon Growth 119

7.4 Directions of Expansion 125

7.5 Forms of Growth 129

7.6 Conclusions 131

8 Vertical Integration 133

8.1 Introduction 133

8.2 Strategic Gains from Vertical Integration 133

8.3 Costs of Vertical Integration 137

8.4 Policy on Vertical Integration $\quad 140$

8.5 Conclusions 144 
D Diversification 149

9.1 Introduction 149

9.2 Diversification 152

9.3 Management Issues $\quad 155$

9.4 Strategy Variables $\quad 159$

9.5 Conclusions 165

10 Acquisitions and Mergers 170

10.1 Definitions and Statistics $\quad 170$

10.2 Acquisition and Merger Goals 171

10.3 Merger Performance 177

10.4 Reasons for Merger Failure $\quad 179$

10.5 Merger Guidelines 182

10.6 Conclusions 192

1 Divestment 199

111.1 Introduction 199

11.2 Reasons for Divestment 202

11.3 Management Considerations 208

11.4 Conclusions 211

12 Business Failure and Turnaround 213

12.1 Introduction 213

12.2 Business Failure or Decline 215

12.3 The Corporate Turnaround Process 219

12.4 Turnaround Case Histories 221

12.5 Conclusions 229

Conclusions 233

13.1 Introduction 233

13.2 Reservations 233

13.3 Conclusions 240

Index $\quad 243$ 


\section{Acknowledgements}

Although writing this book has been very largely a solo effort, I am nonetheless grateful for this conventional opportunity to acknowledge various debts of gratitude to those who through their writings or otherwise have influenced or assisted me in writing this book.

There are many intellectual debts. I have drawn heavily upon the existing textbook, monograph and journal literature in the field of corporate strategy. Where I have taken a point from that literature into this text directly I have made the usual acknowledgement through appropriate reference. I am also grateful at a more general level to these writers for the stimulus with which their work has provided me. On occasion I have reproduced diagrams or tables from journals and books, and I am grateful to the editors of the Journal of Marketing, Long Range Planning and Management Today and to the publishers Harper \& Row, McGraw-Hill and John Martin for their permission to reproduce these. I am also particularly grateful to the editor of the Financial Times for permission to reproduce the article from that newspaper which appears in Chapter 6. Although time has prevented me from benefiting from the views of others on draft chapters of this text I am indebted to a number of colleagues for their advice and help in directing me to references in the literature and discussing these with me. I am particularly grateful in this context to my Management Faculty colleagues Kishen Srinivasan, Robert Pemble, Tina Walley, Ian Glover and Roy Hutchison. I am also indebted to the 
library staff at Dundee College of Technology for their assistance in obtaining access to a wide range of literature in the corporate strategy field which I have used in my teaching and which has been incorporated into this text.

My wife and family have again borne with me in the writing of this book, which was largely carried out during what some other professions would regard as unsocial hours. This domestic support and assistance is much appreciated.

June 1985

W. Stewart Howe

The author and publishers wish to thank the following who have kindly given permission for the use of copyright material:

Philip Allan Publishers Ltd for tabulated points from Business Policy, by R. E. Thomas, 2nd edn 1983, p. 114.

American Marketing Association for a table from an article by G. S. Day in the Journal of Marketing, April 1977, p. 32.

Financial Times Business Information Limited for 'The Long Search that Led to Howard Johnson's Door'.

Harvard Business Review for a exhibit from 'The Industrial State: Old Myths and New Realities' by Bruce R. Scott, March - April 1973.

B. Hedley for 'Strategy and the "Business Portfolio"' in Long Range Planning, February 1977, p. 10; B. W. Denning for 'Strategic Environmental Appraisal' in Long Range Planning, March 1973, p. 26; and D. E. Hussey for 'Portfolio Analysis: Practical Experience with the Directional Policy Matrix', Long Range Planning, August 1978, pp. 3-4.

Managing Today for the article 'The Strategy of Merging' by John Kitching, Management Today, October 1969.

Every effort has been made to trace all the copyright holders, but if any have been inadvertently overlooked the publishers will be pleased to make the necessary arrangement at the first opportunity. 


\section{Introduction}

This text is concerned with the topic of corporate strategy, which is about the decisions which senior management make regarding how a business organisation should relate to its product market environment. The book is designed to be of use to business or management students following a one-year course in the subject area who have previously studied economics, accounting and behavioural sciences, and who also have some knowledge of functional areas of business such as marketing. The author has used the material in the text with final-year business studies students and also those studying for the part-time Diploma in Management Studies.

Practitioners of corporate strategy need to have an understanding of the variables which they should take into account in arriving at strategic decisions, of the strategies open to businesses, and of how possible strategies should be evaluated. They also require to know something of how particular business strategies such as vertical integration or divestment work, and the problems surrounding the appraisal and undertaking of these strategies. For these reasons the text is divided into two parts. Part I, Chapters $1-6$, is concerned with the strategic decision-making process: a sequence of analysis, choice and implementation through which senior management should go in determining corporate strategy. Part II of the book offers an analysis of a range of individual business strategies, applying the understanding of the strategymaking process covered in Part I. Part II concludes with a general 
appraisal of the role and significance of corporate strategic decision-making. The advantage claimed for this two-part analysis is that it enables the student to grasp within a relatively short space of time - in the author's experience about ten weeks - the role of the strategic decision-making process. Thereafter in Part II individual business strategies are considered, and readers may choose to study all or part of this section according to their interests and the time available. As a result of this structure a slight degree of repetition is involved in reading the text as a whole. Strategic possibilities outlined in Part I are considered in detail in Part II, and, for example, some common reference to diversification by acquisition appears both in the analysis of the strategy of diversification and in the consideration of acquisition strategies. It is believed that this small degree of repetition will be of value in consolidating an understanding of the strategic management process.

Two further characteristics of the text deserve mention. First, except in one particular case, appropriate examples of the strategies considered have been built into the text rather than isolated or provided by means of separate case histories. It is intended in this way not only to illustrate the use of strategies discussed by means of practical examples, but also to integrate these fully into the text without disturbing the flow of the analysis. Second, a fairly generous list of references is included at the end of each chapter. These are provided not to indicate how widely the author has read, but to allow the interested reader to follow up in detail the individual studies and illustrations relating to any particular strategy. Only in a very few instances is the argument in the body of the text amplified in the references, and the reader whose time is limited may disregard these references without significant loss. 